AN ANALYSIS OF GRAMMATICAL COHESION IN STUDENTS

WRITING RECOUNT TEXT OF GRADE X AT SMA GAJAH MADA

MEDAN

AN ARTICLE

Submitted to Partial Fulfillment of the Requirements for the Degree of Sarjana Pendidikan

BY:

SHANIA TIOPANI PANE

Registration Number: 2161121040

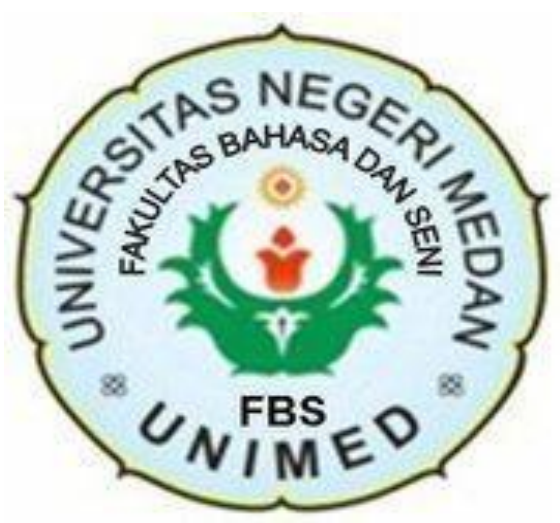

ENGLISH AND LITERATURE DEPARTEMENT

FACULTY OF LANGUAGES AND ARTS

STATE UNIVERSITY OF MEDAN

2021 


\title{
AN ANALYSIS OF GRAMMATICAL COHESION IN STUDENTS WRITING RECOUNT TEXT OF GRADE X AT SMA GAJAH MADA MEDAN
}

\author{
*Shania Tiopani Pane \\ **Isli Iriani Indiah Br. Pane
}

\begin{abstract}
The aim of this study is to define the different types of grammatical cohesion and to look into the grammatical cohesiveness of studentse recount text writings based on the use of grammatical cohesive devices. The research was conducted by using descriptive qualitative method that only focuses on on describing data of grammatical cohesive devices that will be found in studentse recount writings. The data sources are taken from 20 recount texts made by X IS students of SMA Gajah Mada. The data were analyzed used Mayring"s theory which is consists of data categorization, abstraction, coding the text and result. In this research, the data collected through documentation and worksheet. The finding of this study showed that the grammatical cohesive devices found in the data except ellipsis. Furthermore, it can be concluded that all texts collected are cohesive enough because they all employ grammatical cohesion even though some of the cohesive ties are used incorrectly.
\end{abstract}

Keywords: Cohesion, Recount Text, and Descriptive Qualitative

\footnotetext{
*Graduate Status

** Lecturer Status
} 


\section{Introduction}

As an international language, English plays an important role as a means of communication among people in the world for business, science, economy, and technology. The Education Ministry of Indonesia includes English as a compulsory subject to learn in Junior High School up to Senior High School states that in learning English, there are certain skills that students need to learn, namely: listening, speaking, reading, and writing. As a productive skill, writing is not like speaking skills nor other receptive skills. Writing is the most difficult skill for not only it needs a lot of vocabularies in composing paragraph, but also grammatically correct to be comprehensible besides other writinges rules.

Based on an observation conducted in SMA Gajah Mada, the students have many problems in learning English as a foreign language. One of the general problems faced by the students is when they explore their idea in written form like writing genres. There are many areas encountered by the students when they are ordered writing genres. From the writeres observation, the common problems appear in writing genres at least five areas, they are problems in content, organization, vocabulary, grammar, and mechanics.

Because of all the problems, the writer interested to analyze it. The writer only focuses on the use of grammatical cohesion and will try to combine the problems above and conducted to the level of senior high school. Therefore, the writer will investigate grammatical cohesive devices 
in students ${ }^{\text {ee }}$ recount text as well as the grammatical cohesiveness of the text based on the use of the grammatical cohesive devices.

\section{Text}

A text is a body of language. Hartman and Hartman (1996:202211) state that the text is to express an opinion or experience in writing. When we analyze it, we analyze the product of this process, and the term „text $\mathrm{t}^{\mathrm{ee}}$ is usually taken as referring to the product.

From the explanation can be concluded that it is something which is spoken or written can be said as a text if it has texture, cohesive ties, and structures. It could consist of a single word like Ladies or Gentlemen ${ }^{e e}$ on a toilet door right up to a complete book and can be either written or spoke . The text is the main written or printed part of a book and the written form of speech, or article and any form of written material. When these words are put together to communicate a meaning, a piece of text is created.

In general, any unit which is structured hangs together in such a manner to form text. Structure is one means of expressing texture.

\section{Recount Text}

Anderson and Anderson (1997: 48) state that recount text is a piece of text which retells past events orderly and has a purpose to describe what have already happened. 
Recount is a kind of genre that has social function to retell event for the purpose of informing or entertaining. Similarly, Gerot and Wignell (1994: 194) state that recount is retelling past events in order to inform or entertain about what and when it happened. Recounts are generally based on the direct experience of the author, but it may also be imagined or outside the authores experience. In recount text, a writer tells a reader about his/her personal experience or tells others experience to readers. In other words, recount text is a text which retells events or experience in the past.

Regarding the limitation of this study, it only focused on student $\mathrm{s}$ recount text writing and especially the use of grammatical cohesive devices.

\section{Grammatical Cohesion}

Halliday and Hasan (1976:8) classify the categories of grammatical cohesion into four types: reference, substitution, ellipsis, and conjunction.

From the explanation above can be concluded that grammatical cohesion can be divided into four types. They are reference, subtitution and ellipsis, and conjunction. Grammatical cohesion refers to grammatical items which are used to connect clauses in a text to make the meaning cohesive. The cohesive devices are function to link various lexico grammatical elements in a text to convey meaning relations. Cohesion means relation, relatedness, connection, connectedness, link and chain (Rogert's Thesaurus). An important contribution to coherence comes from 
cohesion and cohesion is a set of linguistic resources for linking one part of a text to another. Cohesion is a semantic relations between an element and some other elements in the text (Halliday \& Hasan, 1976:8). Cohesion is a semantic relation, but text is a semantic unit. Cohesion in a text can be analyzed through the linguistics devices which are called the cohesive devices. Cohesion is represented in two modes such as grammatical cohesion and lexical cohesion (Halliday \& Hasan, 1976:6).

All of them are very important to study because they take a big role in making a cohesiveness in a text and they help the people to understand the unity of the text easier.

\section{Methodology}

The research was conducted by using descriptive qualitative research which purposed to focus and to find out on describing data of grammatical cohesive devices and in students ${ }^{\text {ee }}$ recount writings. . In short, this method described intensive and specific how the tenth grade students ${ }^{\text {ee }}$ ability in building cohesion devices in writing recount text.

The subject of this study is the grade X IPS with 20 students of SMA Gajah Mada Medan. The data were collected through using students ${ }^{\text {ee }}$ worksheet and documentation. The data collected by using descrptive approach.

In this study, the data collected from the students ${ }^{\text {ee }}$ worksheet and documentation get from the students. 


\section{Findings}

The writer calculated the percentage of grammatical cohesion by dividing the total of every cohesion with the total of all cohesion and times $100 \%$. It is general from that used in mathematic.

$\frac{59}{203} \times 100 \%=29 \%$ of reference

$\frac{3}{203} \times 100 \%=1 \%$ of substitution

$\frac{144}{203} \times 100 \%=70 \%$ of conjunction

Based on percentage above, it can be seen that the highest percentage was $70 \%$ on conjunction and the lowest percentage was $1 \%$ on substitution. In conclusion, the most widely used of cohesive devices in students ${ }^{\text {ee }}$ theses were conjunction. It serves to bind parts of a text and to mark the difference between the stage. In line with Scott and thompson (2001, p.4) state that conjunction refers to links between clauses or the ways in which the different parts of a text fit together.

The table shows the number of cohesive devices in all texts but not all categories of cohesive devices occur in the data. It can be seen that most frequent cohesive devices used are reference and conjunction.

From the data above, most of the students Gajah Mada Senior High School are using conjunction 144 items (70\%), as the highest rank found in the students writing than others devices, additive conjunction (81 items), adversative conjunction (11 items), causal conjunction (27 items) and temporal conjunction (25 items). The second position is reference with 59 items (29\%), they are personal pronoun (20 items), possessive 
determiners (27 items), possessive pronoun (1 items) and demonstrative reference (11 items). And the lowest position is substitution with 3 items $(1 \%)$.

\section{a. Result}

The following discussion is based on the previous results. According to Matthiessen (2014, p. 603), there are four types of grammatical cohesion: reference, substitution, ellipsis and conjunction. Each of them stands as grammatical cohesive devices that has its own character.

Based on the findings above, cohesive devices were found on students $^{\text {ee }}$ writing recount text. The first type was grammatical cohesion. Grammatical cohesive devices include reference, substitution, ellipsis and conjunction. All of students used grammatical cohesion in their recount text especially in reference and conjunction. This confirms that the students already knew these devices. The highest frequency of the used grammatical cohesion was conjunction. They appeared in all of their writing recount text.

It showed by the total appeared, there were 144 items found in conjunction. This fact indicated that the students have been familiar with this kind of cohesive devices.

\section{b. Discussion}

This study aimed to investigate the students ${ }^{e e}$ ability in writing text of the tenth grade students of SMA Gajah Mada. Grammatical cohesive is a type of cohesion that uses grammar to determine the semantic relation. In grammatical cohesion, the relationship between and within a text is signed by 
means of grammatical elements. It consists of reference, conjunction, substitution, and ellipsis. Reference sits in the first position among all sub categories of grammatical cohesion. Then, it is followed by conjunction, substitution and ellipsis. There are several examples types of grammatical cohesion that found from the data.

\section{- References}

Reference is concerned with the relation between words and extra- linguistic reality. Moreover, Hidayat (2016) define that reference is when one word refers to the other word.

\section{1) Personal Reference}

Personal reference is reference by means of function in the speech situation, thought the category of person. There are three class of personal reference: personal pronouns, possessive adjectives (possessive determiners), and possessive pronouns (Halliday \& Hasan in Suningsih, 2016: p.21). In the data that taken from the student are found some used of personal reference, as follow:

a) Personal pronoun

a. Last Friday, my family and I had a vacation to the pool. It's fun, we went in the morning.

b. When Nadra left me, she took me a free ticket.

The pronoun "we" in (a) shows personal reference that refers to "my family and I". Meanwhile, "she" in (b) is personal reference that refers to "Nadra" in the previous sentences. The two examples above show the way of referring used by students to build the semantic relation within and 
between sentences. These ways of referring are used together in the adjoining sentences to ease the comprehension to readers.

morning". While, "there" is used represent someone in that place.

- Conjunction

Conjunction is a word which merely joins together sentences and sometimes word (Wren and Martin in Hidayat, 2016). In addition, Hidayat (2016) define that conjunction joins together sentence and often makes them more compact. There are four kinds of conjunction; additive conjunction, adversative conjunction, causal conjunction, and temporal conjunction.

a) Additive Conjunction

a. He saw a creature that resembled a very scary white hood and I came to see what happened.

b. I just wanted to come and see if there was any good movie.

"And" in the text above were additive conjunctions which as a conjunction relation that support to the previous sentence.

\section{Conclusion}

After analyzing the students recount text about cohesion devices, the writer found that the most frequent types of cohesive devices made by the participants included reference (29\%), conjunction (70\%), substitution (1\%) and ellipsis $(0 \%)$ 
First, research of the result shows the types of cohesive devices made by the tenth grade students of Senior High School Gajah Mada are conjunction 144 items (70\%), as the highest rank found in the students writing than others devices, additive conjunction (81 items), adversative conjunction (11 items), causal conjunction (27 items) and temporal conjunction (25 items). The second position is reference with 59 items (29\%), they are personal pronoun (20 items), possessive determiners (27 items), possessive pronoun (1 item) and demonstrative reference (11 items). The highest frequency of the used reference was possessive determiners. The next frequently used references were substitution and ellipsis, found used in students writing. There were one substitution device found. It means that the students had good enough competence in producing cohesion in their writing text, because they utilized all the types of cohesion at their writing text except ellipsis and also substitution was hardly found.

\section{Suggestion}

Based on the conclusion above, the writer would like to give suggestions to the teacher, students and other researchers. For the teacher, they should give more attention to the teaching of cohesion devices in writing, especially in the use of cohesive devices. They also have to give a wider explanation to the students about kinds, functions, and positions of cohesion devices within or among sentences. The teacher needs to evaluate students writing performance, construct remedial teaching, and give understanding that students are in need of continuous and special supervision conducted by teacher during writing activities. For the students, they have to improve their 
writing skills, especially about cohesive devices. And also the students need to be aware of how to write cohesively and never stop learning and practicing writing good texts. Then for the other researchers, he or she could investigate the use of cohesive devices writing other type of text. This study is also suggested to be conducted further as references. 


\section{REFERENCES}

Alarcon, J. \&. (2011). Grammatical cohesion in students argumentative essay. International Journal of English and Literature, 114-127.

Andani, M. R. (2019). Andani, The Use of Conjunction in Students' Writing Recount Text at Second Grade of SMAN 1 Tongkuno. Journal of Teaching of English, 437-451.

Andayani, P. O. (2014). An Analysis of The Cohesion and Coherence of The Students' Narrative Writings in SMP Negeri 2 Banjar. Jounal of English Language Education Program Post Graduate Program of Ganesha University of Education Singaraja, 13.

Farida, A. N. (2019). Students ${ }^{\text {ee }}$ Writing Quality: Its Coherence and Cohesion. Journal of Language and Literature, 14(1), 121-129.

Gerot, L. W. (1994). Making Sense of Functional Grammar.

Harris, A. A. (2014). An Analysis of Studentse Difficulties in Writing Recount Text at Tenth Grade of SMA Negeri 1 Sungai Limau. English Language Teaching (Elt), 2.

Jabeen, I. M. (2013). Ellipsis, Reference \& Substitution as Cohesive Devices The Bear by Anton Chekhov. Academic Research International, 4(6), 123.

Khalil, A. (1989). A study of Cohesion and Coherence in Arab EFL College Students' Writing. System, 17(3), 359-371.

Kuo, C. H. (1995). Cohesion and Coherence in Academic Writing: From Lexical Choice to Organization. RELC Journal, 26(1), 47-62.

Masithoh, H. \&. (2017). Grammatical Cohesion Found in Recount Texts Of "Pathway to English" X Grade Curriculum 2013 General Program by Erlangga. Journal for Language and Foreign Language Learning, 6(1), $77-95$

Matthiesen. (2014). Introduction to functional grammar. Routledge, USA.

Putra, A. I. (2018). An Analysis of The Use of Grammatical and Lexical Cohesion in Theses Written by Undergraduate Students Majoring in English of Islamic University of Riau. Journal of Linguistics and Language Teaching, 4(1), 72-90.

Saragih, N. S. (2014). The Effectiveness of Using Recount Text to Improve Writing Skill for Grade III Students of Kalam Kudus Elementary School 2 Pematangsiantar. Journal Of Humanities and Social Science (IOSR-JHSS), 19(1), 56-64.

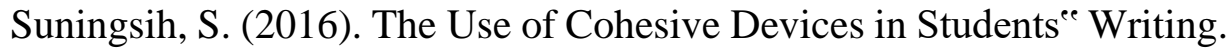
Bandar Lampung. 